\author{
D. Cusimano, R. Guarino \& V. Ilardi
}

\title{
Discovery of a second locality for the narrow endemic Anthemis ismelia (Asteraceae) in NW Sicily
}

\begin{abstract}
Cusimano, D., Guarino, R. \& Ilardi, V.: Discovery of a second locality for the narrow endemic Anthemis ismelia (Asteraceae) in NW Sicily. — Fl. Medit. 27: 151-158. 2017. — ISSN: 11204052 printed, 2240-4538 online.

A new population of Anthemis ismelia (Asteraceae) has been discovered on Mt Pecoraro (Cinisi, NW Sicily), a limestone headland at about $14 \mathrm{~km}$ from Mt Gallo (Palermo), the locus classicus et unicus of this species described in 1884. Taxonomic framework, distribution update, habitat characterisation, ecology and phytosociological framework are provided, as well as meta-population numerical estimates and risk status assessment.
\end{abstract}

Key words: chasmophyte, endangered flora, IUCN Direct Threats and assessment, phytosociology.

\section{Introduction}

In spring 2014, floristic field sampling in the mountains surrounding Palermo (NW Sicily) yielded the discovery of a new population of Anthemis ismelia Lojac. on the western side of Mt Pecoraro near the town of Cinisi. This species, ascribed to Anthemis sect. Hiorthia, was hitherto known only for the shady, north-facing limestone cliffs of Mt Gallo near Palermo, about $14 \mathrm{~km}$ far from the newly discovered population [Lojacono-Pojero 1884 (sub A. punctata Vahl), 1903; Bartolo \& al. 1981]. In spring 2015 and 2016, some scattered plants were found in the northern side of Mt Pecoraro during field work to confirm and assess the consistency of the newly discovered population (Fig. 1).

The aim of the present contribution is to elucidate the taxonomic framework of the species, to update its distribution range, to provide information on the growing sites (habitat, geology, bioclimate, and phytosociological affiliation), to document the so far known metapopulations and to assess the risk status according to the IUCN criteria.

\section{Materials and methods}

The species was identified based on the diagnostic characters reported in the original description and in the Flora Sicula (Lojacono-Pojero 1888-1909), Flora d'Italia (Pignatti 1982), 

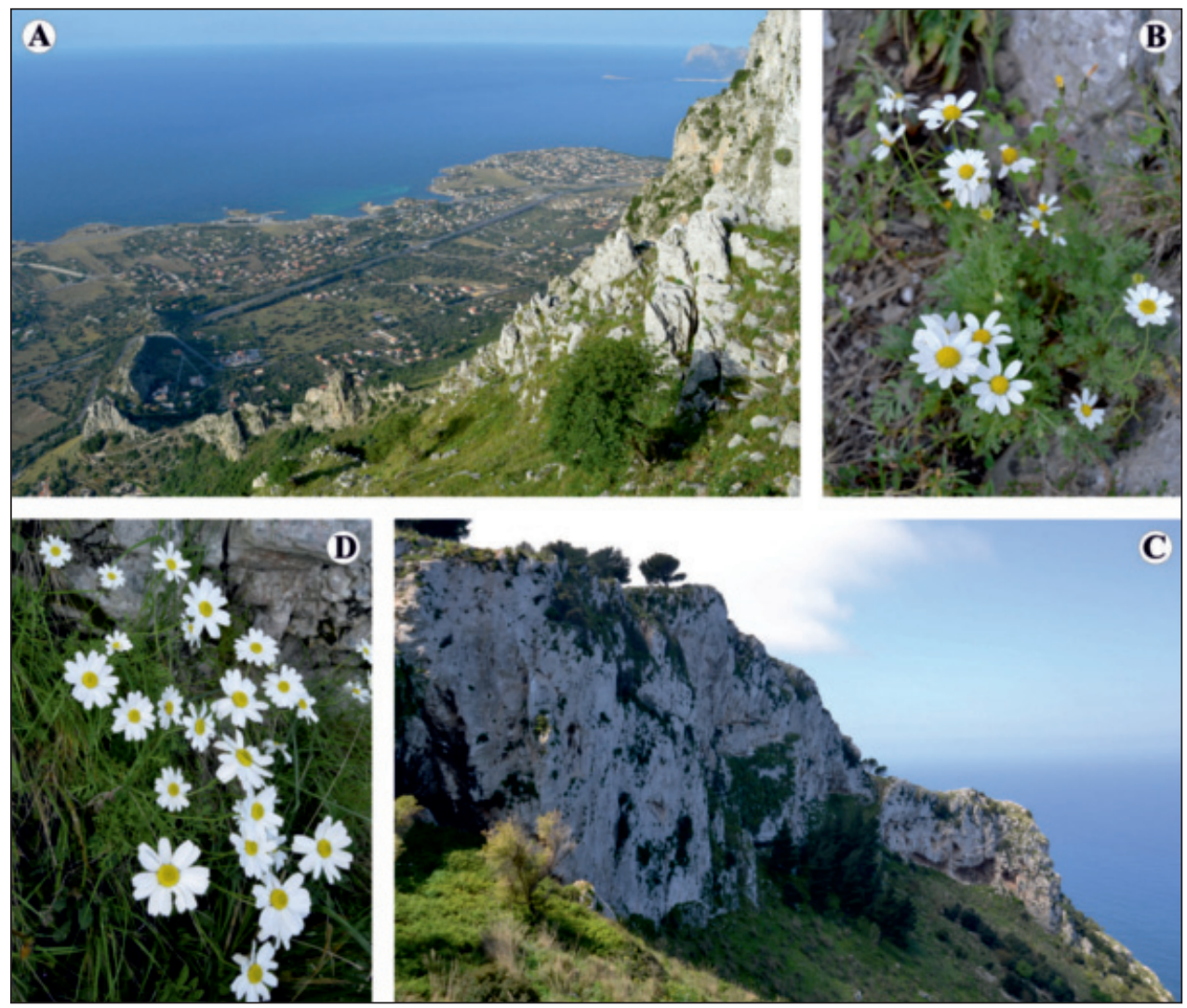

Fig. 1. Natural habitat and flowering stems of Anthemis ismelia: A-B at Mt Pecoraro (from which on the horizon right you can glimpse Mt Gallo); C-D at Mt Gallo.

and Flora Europaea (Tutin \& al. 1976), as well as on the comparative analysis of herbarium specimens and of living plants collected in Mt Pecoraro and Mt Gallo. The specimens collected during the field research have been dried and stored in the Herbarium Mediterraneum Panormitanum (PAL). Taxonomic nomenclature follows Giardina \& al. (2007).

For the climatic characterization of the growing sites, reference was made to rainfall and temperature measurements of weather stations next to the surveyed sites, according to the data provided by the Hydrographic Service of the Sicilian Region (Ministero dei LL. PP. 1926-85) and processed by Duro \& al. (1996). The bioclimatic classification follows Rivas-Martínez (2008), and the spatial analysis of the bioclimatic units of Sicily reported in Bazan \& al. (2015) and in the Climatological Atlas of Sicily (Drago 2005).

In order to update the risk status of the species, after the discovery of this new population at Mt Pecoraro, the entire surface of the sites was surveyed for current threats (IUCN-CMP 2012), extent of occurrence (EOO) and area of occupancy (AOO) - calculated by the $1 \times 1$ $\mathrm{km}$ Universal Transverse Mercator (UTM) grid - and effective AOO, according to the IUCN Red list category and criteria (IUCN Standards and Petitions Subcommittee 2017). 


\section{Results}

\section{Taxonomic framework and morphological traits}

The Anthemis punctata group was recorded in Sicily already by pre-Linnaean botanists, such as Cupani [1696: 48 (sub Chamaemelum montanum, flore magno, Absinthii vulgaris foliis et odore, licet remisso); 1713, vol. 1: plate 195 (sub Chamaemelum Absinthii folio, Parthenii odore); 1713, vol. 3: plate 12 (sub Buphtalmum argenteum flore albo)] and Boccone [1697: 120 (sub Bellis incana Chrysanthemi cretici foliis)]. The first postLinnaean botanist mentioning A punctata in Sicily was Presl (1826), followed by Gussone (1843), who confirmed the occurrence in Sicily of two varieties of $A$. punctata: a typical, glabrous one, and the variety " $b$ " incana, therefore confirming the Cupani's recognition of two forms of "Chamaemelum" from W Sicily. Later on, these two varieties were interpreted by Lojacono-Pojero (1884) as expressions of the morphological variability of $A$. cupaniana Nyman. The same author (Lojacono-Pojero 1884) discovered the $A$. ismelia population of Mt Gallo, near Palermo, which was provisionally referred to A. punctata Vahl (“Symb. bot. 2, p. 9, non Guss. nec Alior.! Desf. fl. Atl. 2, p. 285, tab. 239!!"), providing evidence that this population was different from $A$. cupaniana, particularly in the morphologic features of the achenes (continuous corona and markedly tuberculate ribs).

To circumvent interpretation problems arising from the comparison with the diagnosis provided by Gussone (1843), Lojacono-Pojero (1884) wrote a taxonomic notula on the interpretation and nomenclatural vicissitudes of Anthemis punctata s.l. from Sicily here translated: "On this beautiful species, that should not be confused with the forms of $A$. Cupaniana Tod. (A. punctata Guss.), and on the group of A. montana, I have written extensively in a monographic work still unpublished. I say for now that Gussone has wrongly referred the Sicilian species of our more or less high mountains to this northern African species, which I discovered few years ago in the aforecited places, where it luxuriates in a singular way and grows copious in grassy and shaded places among the ledges of Mount Gallo overlooking the sea. If Gussone had known this species, he would have better clarified the specific forms of the Sicilian Anthemis species, since it is from the knowledge of $A$. punctata that the connection between A. cupaniana and A. montana can be figured out; it is very intimate in a few cases, but never to the point of making ambiguous the knowledge of the two types, because it can be said that in Sicily, except for the high mountains of Nebrodi, the subspecies cupaniana occurs everywhere with its innumerable forms, whereas A. montana assumes that form I have seen common in all of Italy, which is A. columnae Ten.".

Based on Lojacono-Pojero's (1884) notula and on his direct knowledge of the morphological traits of the North African populations of A. punctata Vahl, Fiori (in Fiori \& Paoletti 1903) highlighted the distinctive and peculiar characters of the Sicilian population of Mt Gallo and dedicated it to the Sicilian botanist Lojacono-Pojero through the nomenclatural combination Anthemis punctata Vahl var. b Lojaconi Fiori in Fiori \& Paoletti. Almost simultaneously, Lojacono-Pojero (1903), in his Flora Sicula, described as a new species, Anthemis ismelia, the population of the "... northern slopes overlooking the sea in wild shady and stony places on arable stony soil or on the cliffs at Mount Gallo, on the side of Sferracavallo at Malo Passo". Afterwards, Fiori (1926) refers Anthemis ismelia Lojac. to Anthemis punctata var. $\gamma$ Lojaconi Fiori. 
Anthemis ismelia Lojac., Flora Sicula 2(1): 78 (1903) [Syn.: Anthemis punctata Vahl, Symb. Bot. 2: 91 (1791); Anthemis punctata f. b lojaconi Fiori in Fiori \& Paoletti, Fl. Analitica Ital. 3: 258 (1903)]. Lectotype [designated by Aghababyan \& al. (2008: 517)]: "Flora selecta exsiccata, Publié par Ch. Magnier. 1463. - Anthemis Ismelia Lojacono Sp. nova. - A punctata Loj olim in contrib. fl sic. in Nat. sic. (Guss. ex parte! an Vahl ??) - A. Cupaniana Tod. ex parte! Sicile: rochers ombragés, mont Gallo. Avril-Mai 1887. M. Lojacono.”.

Currently, according to Greuter (2008), the Anthemis punctata aggregate includes $A$. cupaniana, A. ismelia, and A. punctata [with subsp. punctata and subsp. kabylica (Batt.) Oberpr.], to which is to be added A. pignattiorum Guarino, Raimondo \& Domina, an isolated species recently described for the Hyblean Plateau (SE Sicily) by Guarino \& al. (2013).

According to the chromosomal analysis, $A$. ismelia is diploid $(2 n=18$; Bartolo \& al. 1981), and, therefore, it could be a possible ancestor of $A$. cupaniana that is tetraploid (Brullo \& al. 1978). All representatives of the A. punctata aggregate are suffruticose or herbaceous perennials with very limited vegetative reproduction, typically forming scattered populations of caespitose individuals up to $70 \mathrm{~cm}$ tall, with dissected leaves and showy inflorescences (Oberprieler 1998). Plants flower from April to June, but extra-seasonal flowering of few individuals from September to December is not a rare event. Capitula are pollinated mainly by native bees and are likely to be self-incompatible, even if incompatibility was not tested. The fruits, epappus achenes, are dispersed by gravity and through mirmecochory.

\section{Distribution and habitat}

Anthemis ismelia is a rare endemic chasmophyte restricted to two sites in NW Sicily (Fig. 2), where it grows on north- to west-facing vertical cliffs at an elevation of 10-500 $\mathrm{m}$ a.s.1. at Mt Gallo, near Palermo, and 400-650 m a.s.l. at Mt Pecoraro, near Cinisi. Both sites fall within Meso-Cenozoic calcareous rocks of the Panormide Units, a carbonate platform constituting the skeleton of the northernmost sector of Palermo Mountains. These are part of the Sicilian "Fold and Thrust Belt", which, at the boundary between the African and the European plates, links the African Maghrebides to the Calabrian arc subduction complex and to the Southern Apennines (Catalano \& al. 2013).

Both growing sites fall into the Mediterranean pluviseasonal oceanic bioclimate (RivasMartínez \& al. 2004), with lower subhumid ombrotype and upper thermomediterranean (Mt Gallo) and lower mesomediterranean (Mt Pecoraro) thermotype (Bazan \& al. 2013). These bioclimatic conditions, however, are buffered and cooled by a daily moisture condensation, often forming a very dense fog, due to the humid sea breeze arising from the Tyrrhenian Sea, right off the limestone cliffs where A. ismelia grows. The outstanding floristic value of the huge vertical cliffs of Mt Gallo and Mt Pecoraro is emphasised by a long list of endemic or subendemic species like Brassica rupestris Raf., Centaurea panormitana Lojac. (see Domina \& al. 2016, 2017 for the use of the name), Cymbalaria pubescens (C. Presl ) Cufod., Dianthus rupicola Biv. subsp. rupicola, Euphorbia bivonae Steud., E. melapetala Gasparr., Galium pallidum C. Presl, Glandora rosmarinifolia (Ten.) D.C. Thomas, Helichrysum panormitanum Guss. subsp. panormitanum (on Mt Pecoraro) and subsp. stramineum (Guss.) C. Brullo \& Brullo (on Mt Gallo), Iberis semperflorens L., Lomelosia cretica (L.) Greuter \& Burdet, Micromeria graeca subsp. fruticulosa (Bertol.) Guinea, Odontites bocconei (Guss.) Walp. subsp. bocconei, Pseudoscabiosa limonifolia 


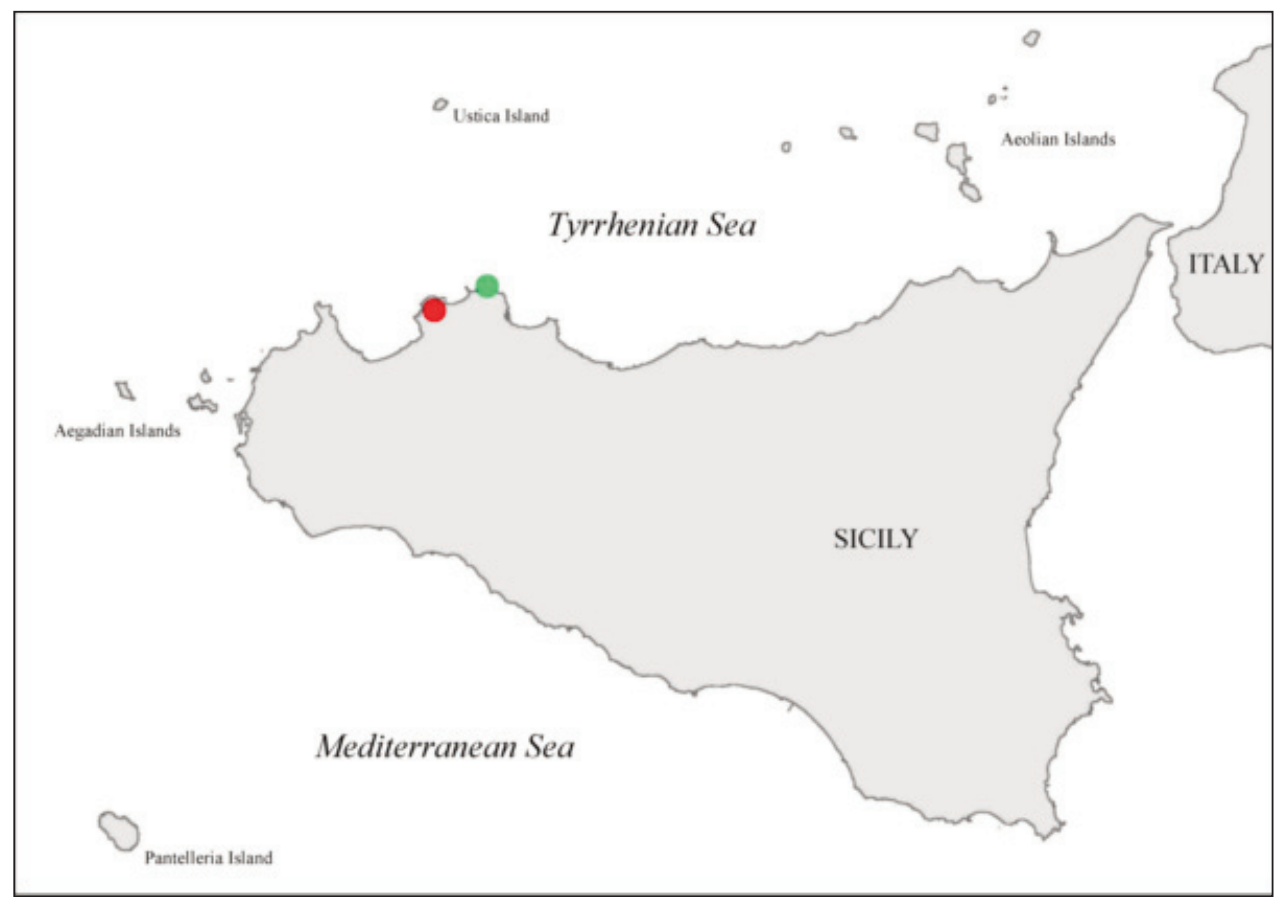

Fig. 2. Geographical range of Anthemis ismelia: the new population at Mt Pecoraro (red dot) and the single hitherto known location at Mt Gallo (green dot) in NW Sicily.

(Vahl) Devesa, Seseli bocconei Guss., Silene fruticosa L. Besides of these species, occurring on both sites and exhibiting a broader distribution range, other ones are narrowly endemic to one of the two sites: Genista gasparrini (Guss.) C. Presl, Hieracium lucidum Guss. subsp. lucidum and Limonium panormitanum (Tod.) Pignatti are endemic to Mt Gallo; Limonium poimenum Ilardi, Brullo, D. Cusimano \& Giusso is endemic to Mt Pecoraro (Ilardi \& al. 2014).

This endemic-rich chasmophitic vegetation has been described as Scabioso creticaeCentaureetum ucriae Brullo \& Marcenò 1979 anthemidetosum ismeliae (Brullo \& Marcenò 1979) Brullo, Marcenò \& Siracusa 1998, belonging to the alliance Dianthion rupicolae Brullo \& Marcenò 1979, to the order Asplenietalia glandulosi Br.-Bl. in Meier \& Br.-Bl. 1934 and to the class Asplenietea trichomanis (Br.-Bl. in Meier \& Br.-B1. 1934) Oberd. 1977 (Brullo \& Marcenò 1979; Brullo \& al. 1998).

\section{Conservation status}

Anthemis ismelia was previously assessed as Vulnerable: VU (Walter \& Gillett 1998), and after as Critically Endangered: CR (criteria B1+2c, D; Buord \& Lesouëf 2006; Council of Europe 2012). Even if the habitat of the species should represent a stable environment and the discovery of a new population doubled the overall population size, when applying the IUCN-CMP Unified Classification of Direct Threats (IUCN-CMP 2012), some threats 
for the species were detected, mainly ascribable to the following categories: 2.3.1 Nomadic Grazing (especially the goat grazing in the wildness); 6.1 Recreational activities (especially rock climbing); 7.1.1 Increase in Fire Frequency/Intensity (arsons affect both sites almost yearly, especially that of Mt Gallo); 12.1 Other Threat (risk factors intrinsic to the species are related to the relictual nature of the sites, to the habitat fragmentation and to the exiguous numerical consistency of the metapopulations). Overall, these threats represent undoubtedly a barrier to the dispersal of the species, affecting its current distribution and the number of mature individuals. Therefore, although the two metapopulations fall within Sites of Community Importance (SCI ITA 020006 "Capo Gallo" and SCI ITA 020021 "Montagna Longa e Pizzo Montanello"), a Special Protection Area (SPA ITA 020049 "Monte Pecoraro e Pizzo Cirina") and a regional wildlife preserve (Oriented Natural Reserve "Capo Gallo"), their exiguity (the population size is in both cases fewer than 100 mature individuals), restricted localization (extent of occurrence estimated in 22 $\mathrm{km}^{2}$, with an area of occupancy of $9 \mathrm{~km}^{2}$ and an effective area of occupancy of about 0.38 $\mathrm{km}^{2}$ ) and fluctuation in the number of mature individuals, allow, according to the IUCN Red list category and criteria (IUCN Standards and Petitions Subcommittee 2017), to confirm Anthemis ismelia as Critically Endangered: CR [criteria B1ab(iii,v)c(iv)+2ab(v)c(iv); C2b], as also stated by other authors (Raimondo \& al. 2011).

In both sites the protection measures are not effective in preserving the integrity of this species, because nothing is known about its reproductive fitness and seed bank status, nor about its genetic variability within and among populations. These factors are very important for defining functional populations (those with members that exchange genes), for identifying potential targets to ensure the conservation of the species domains and evaluating opportunities for in situ and ex situ conservation programs. Reduced pollen exchange due to inbreeding, localized pollination, very limited dispersal of seeds are likely to affect the two existing populations, but nothing has been done so far to assess it properly.

Even if the population size is monitored in situ and some living specimens are grown in the Botanical Garden of Palermo, this species requires intensive investigation efforts and stronger conservation measures, including specific and more effective in situ and ex situ conservation programmes.

\section{Acknowledgements}

Thanks are due to two anonymous referees for their suggestions and constructive criticism, as well as to Alfonso La Rosa for his kind support in the field sampling.

\section{References}

Aghababyan, M., Greuter, W., Mazzola, P. \& Raimondo, F. M. 2008: Typification of names of Compositae taxa described from Sicily by Michele Lojacono-Pojero. - Fl. Medit. 18: 513-528.

Bartolo, G., Brullo, S. \& Pavone, P. 1981: Números cromosomáticos de plantas occidentales, 138156. - Anales Jard. Bot. Madrid 38(1): 289-299.

Bazan, G., Marino, P., Guarino, R., Domina, G. \& Schicchi, R. 2015: Bioclimatology and vegetation series in Sicily: a geostatistical approach. - Ann. Bot. Fenn. 52: 1-18. doi: $10.5735 / 085.052 .0202$ 
Boccone, P. 1697: Museo di piante rare della Sicilia, Malta, Corsica, Italia, Piemonte, e Germania. Venetia.

Brullo, S. \& Marcenò, C. 1979: Dianthion rupicolae nouvelle alliance sudtyrrhenienne des Asplenietalia glandulosi. - Doc. phytosociol., n. sér. 4: 131-146.

—, — \& Siracusa, G. 1998: La classe Asplenietea trichomanis in Sicilia. - Colloq. Phytosociol. 28: 467-538.

—, Majorana, G., Pavone, P. \& Zizza, A. 1978: Numeri cromosomici per la flora italiana: 375-381. - Inform. Bot. Ital. 10: 57-63.

Buord, S. \& Lesouëf, J. Y. 2006: Consolidating knowledge on plant species in need for urgent attention at European level. - Paris and Brest.

Catalano, R., Basilone, L., Di Maggio, C., Gasparo Morticelli, M., Agate, M. \& Avellone, G. 2013: Note illustrative della Carta Geologica d'Italia alla scala 1:50.000. Foglio 594-585 PartinicoMondello. - Roma.

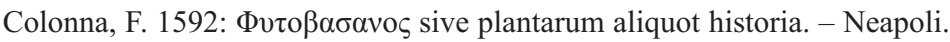

Conti, F., Abbate, G., Alessandrini, A. \& Blasi, C. 2005: An annotated Checklist of the Italian vascular Flora. - Roma.

Council of Europe 2012: Biodiversity and climate change: Reports and guidance developed under the Bern Convention - Volume II (Nature and environment, No. 160). - Strasbourg.

Cupani, F. 1696: Hortus Catholicus. - Neapoli.

- 1713: Panphyton Siculum. - Palermo.

Domina, G., Greuter, W. \& Raimondo, F. M. 2016: Types of names of taxa belonging to the Centaurea cineraria group (Compositae) described from Sicily. Willdenowia 46(1): 23-26. doi: 10.3372/wi.46.46102

- - — \& - 2017: A taxonomic reassessment of the Centaurea busambarensis complex (Compositae, Cardueae), with description of a new species from the Egadi Islands (W Sicily). Israel J. P1. Sci. 64(1-2): 48-56. doi: 10.1080/07929978.2016.1257146

Duro, A., Piccione, V., Scalia, C. \& Zampino, S. 1996: Precipitazioni e temperature medie mensili in Sicilia relative al sessantennio 1926-1985. - Atti 5 Workshop Progetto Strategico "Clima, Ambiente e Territorio nel Mezzogiorno" (Amalfi, 28-30 Aprile 1993), Roma: 17-103.

Drago, A. 2005: Atlante climatologico della Sicilia. Seconda edizione. - Riv. Ital. Agromet. 2: 6783.

Fiori, A. 1926: Nuova Flora Analitica d'Italia, 2(2-3). - Firenze.

— \& Paoletti, G. 1903: Flora Analitica d'Italia, 3. - Padova.

Giardina, G., Raimondo, F. M. \& Spadaro, V. 2007: A catalogue of plants growing in Sicily. Bocconea 20: 3-582.

Greuter, W. 2008: Med-Checklist, 2. - Palermo.

Guarino, R., Raimondo, F. M. \& Domina, G. 2013: A new species of Anthemis sect. Hiorthia (Asteraceae) from SE Sicily. - Pl. Biosyst. 147(3): 821-825. doi: 10.1080/11263504.2013.829888

Gussone, G. 1843: Florae Siculae Synopsis, 1. - Neapoli.

Ilardi, V., Brullo, S., Cusimano, D. \& Giusso del Galdo, G. 2014: Limonium poimenum sp. nov. (Plumbaginaceae), an unusual new species from Sicily. - Phytotaxa 188(5): 268-274. doi: 10.11646/phytotaxa.188.5.4

IUCN-CMP 2012: Unified classification of direct threats, Version 3.2. Available from: http://s3.amazonaws.com/iucnredlist-newcms/staging/public/attachments/3127/ dec_2012_guidance_threats_classification_scheme.pdf [last accessed 8 August 2017]

IUCN Standards and Petitions Subcommittee 2017: Guidelines for Using the IUCN Red List Categories and Criteria. Version 13. Prepared by the Standards and Petitions Subcommittee. 
Available from: http://www.iucnredlist.org/documents/RedListGuidelines.pdf [last accessed 8 August 2017]

Lojacono-Pojero, M. 1884: Studii su piante critiche rare o nuove della Flora di Sicilia. - Naturalista Sicil. 3(7): 213-214.

- 1888-1909: Flora sicula, 1-3. - Palermo.

Ministero dei LL. PP., 1926-85: Annali idrologici. - Palermo.

Oberprieler, C. 1998: The Systematics of Anthemis L. (Compositae, Anthemideae) in W and C North

Africa. Bocconea 9: 1-328.

Pignatti, S. 1982: Flora d'Italia, 1-3. - Bologna.

Presl, C. B. 1826: Flora Sicula, 1. - Pragae.

Raimondo, F. M., Bazan, G. \& Trò̀, A. 2011: Taxa a rischio nella flora vascolare della Sicilia. Biogeographia, n.s., 30: 229-239.

Rivas-Martínez, S. 2008: Global Bioclimatics (Clasificación Bioclimática de la Tierra). Available from: http://www.globalbioclimatics.org/book/bioc/global_bioclimatics-2008_00.htm (last accessed 8 August 2017)

—, Penas, A. \& Díaz, T. E. 2004: Bioclimatic \& Biogeographic Maps of Europe. - León.

Tutin, T. G., Heywood, V. H., Burges, N. A., Moore, D. M., Valentine, D. H., Walters, S. M. \& Webb, D. A. (Eds.) 1976: Flora Europaea, 4. - Cambridge.

Vahl, M. 1791: Symbolae Botanicae, 2. - Hauniae.

Walter, K. S., Gillett, H. J. (Eds.) 1998: 1997 IUCN Red List of Threatened Plants. Compiled by the World Conservation Monitoring Centre. Gland, Switzerland and Cambridge, UK.

Addresses of the authors:

Dario Cusimano ${ }^{1}$, Riccardo Guarino ${ }^{2} \&$ Vincenzo Ilardi $^{3}$,

${ }^{1}$ Department SAAF, University of Palermo, Viale delle Scienze Ed. 4, I-90128

Palermo, Italy. E-mail: dario.cusimano@unipa.it

${ }^{2}$ Department STEBICEF - Botanical Unit, University of Palermo, Via Archirafi 38, I-90123 Palermo, Italy. E-mail: riccardo.guarino@unipa.it

${ }^{3}$ Department DISTEM, University of Palermo, Via Archirafi 26, I-90123 Palermo, Italy. E-mail: vincenzo.ilardi@unipa.it 